\title{
Retinopatili ve Retinopatisiz Diyabetik Hastalarda Dinamik Tiyol Disülfit Dengesi
}

\section{Dynamic Thiol Disulfide Balance in Diabetes With and Without Retinopathy}

\author{
${ }^{1}$ İsa YUVACI, ${ }^{2}$ Nurettin BAYRAM, ${ }^{3}$ Işıl ÇAKIR, ${ }^{2}$ Emine PANGAL, ${ }^{2}$ Seda Duygu SABUR, ${ }^{4}$ Özcan EREL, \\ ${ }^{5}$ Almila ŞENAT
}

\author{
${ }^{1}$ Sakarya Üniversitesi Tıp fakültesi Göz Hastalıkları Anabilim Dalı, Sakarya, Türkiye \\ ${ }^{2}$ Kayseri Sehir Hastanesi Göz Hastalıkları, Kayseri, Türkiye \\ ${ }^{3}$ Kayseri Şehir Hastanesi Biyokimya Bölümü, Kayseri, Türkiye \\ ${ }^{4}$ Yıldırım Beyazıt Üniversitesi Tıbbi Biyokimya Anabilim Dalı, Ankara, Türkiye \\ ${ }^{5}$ Taksim Eğitim Araştırma Hastanesi Biyokimya Bölümü, İstanbul, Türkiye \\ İsa Yuac1: https://orcid.org/0000-0003-0694-9009 \\ Nurettin Bayram: https://orcid.org/ 0000-0003-3244-7328, \\ Iş1l Çakır: https://orcid.org/000-0001-5728-4671, \\ Emine Pangal: https://orcid.org/ 0000-0003-1122-1354 \\ Seda Duygu Sabur: https://orcid.org/ 0000-0001-9999-8082 \\ Özcan Erel: https://orcid.org/ 0000-0002-2996-3236, \\ Almila Şenat: https://orcid.org/ 0000-0002-5806-562X
}

\section{ÖZ}

Amaç: Retinopatisi olan ve olmayan tip 2 diyabetli hastalarda serum tiyol (T) disülfit (D) düzeylerinin ve tiyoldisülfit dengesinin (TDD) karşılaştırılması amaçlandı.

Materyal ve Metot: $B u$ prospektif çalışma göz kliniğinde düzenli takipleri yapılan diyabetli hastalarla, onlara demografik olarak benzeyen gönüllü kontrol grubunda yapıldi. Diyabeti olan ve retinopatisi olmayan hastalar bir grubu (DMG), diyabetik retinopatisi olanlar diğer grubu (DRPG) oluştururken sağl1klı gönüllüler kontrol grubunu (KG) oluşturdu. Rutin göz muayenesini takiben 8 saatlik açlık sonrası kan örnekleri alındı.

Bulgular: Tiyol seviyeleri KG'nda; toplam $\mathrm{T}$ (TT) 375,18 , nativ T (NT) 345,98, D 14,60, D/NT 4,30, D/TT 3,94 NT/TT 92,10 olarak bulundu (oranlar \% olarak degerlendirildi). Bu değerler DMG'unda; 402,97; 361,38; 20,79; 5,99;5,32; 89,34 olarak bulunurken, DRPG'nda ise; 370,$29 ; 329,09 ; 20,60 ; 6,46 ; 5,70 ; 88,59$ olarak bulundu. Gruplar arasında T seviyeleri bakımından bir fark bulunmadı. D değerleri DMG ve DRPG'larında KG'ndan yüksek bulunurken DMG ve DRPG arasında fark bulunmadı. D/NT, D/TT, NT/TT değerlerinde KG ile DMG ve DRPG arasında anlamlı fark bulunurken; DMG ve DRPG arasinda anlamlı fark bulunmadı.

Sonuç: Diyabette zamanla vücuttaki antioksidan sistemlerde oluşan yetersizlik TDD'inde değişikliklere yol açmaktadır. Çalışmamızda D değerleri DMG ve DRPG'larında yüksek bulundu, TDD bozulmuş izlendi.

Anahtar Kelimeler: Disülfit, diyabet, retinopati, tiyol

\section{ABSTRACT}

Objective: Comparison of serum thiol (T) and disulfide (D) levels and thiol-disulfide balance (TDB) in type 2 diabetic patients who have retinopathy or not.

Materials and Methods: The diabetic patients were divided into two groups as patients without diabetic retinopathy (DMG) and patients with diabetic retinopathy (DRPG) and compared to the control group (CG), which included the healthy volunteers with similar demographics. Following a complete eye examination, blood samples were drawn after fasting for at least 8 hours.

Results: The total T (TT), native T (NT), D, D/NT, D/TT, and NT/TT were $375.18,345.98,14.60,4.30,3.94$, and 92.10 in the CG, respectively. These values were 402.97 , $361.38,20.79,5.99,5.32$, and 89.34 in the DMG, and $370.29,329.09,20.60,6.46,5.70$, and 88.59 in the DRPG, respectively. In contrast, $\mathrm{D}, \mathrm{D} / \mathrm{NT}$, and $\mathrm{D} / \mathrm{TT}$ values were significantly higher in the DMG and DRPG compared to the CG. However, no significant differences were detected between DMG and DRPG.

Conclusion: This study shows that the $\mathrm{D}$ values were high in the DMG and DRPG, causing impaired TDB. Our results suggest that the body's antioxidant systems are inadequate over time in diabetic patients, which leads to changes in TDB in the body.

Keywords: Diabetes, disulphide, retinopathy, thiole

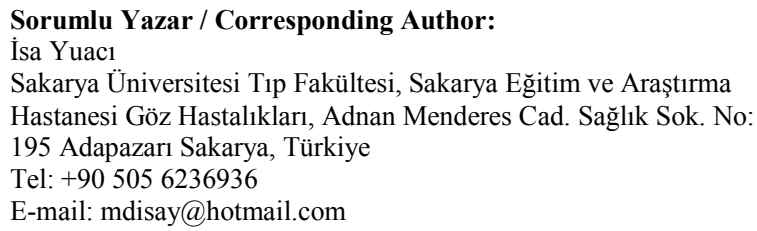

\section{Yayın Bilgisi / Article Info:}

Gönderi Tarihi/ Received: 05/01/2021

Kabul Tarihi/ Accepted: 24/03/2021

Online Yayın Tarihi/ Published: 05/06/2021

\section{Atıf / Cited: Yuvacı İ ve ark. Retinopatili ve Retinopatisiz Diyabetik Hastalarda Dinamik Tiyol Disülfit Dengesi. Online Türk Sağlk Bi-} limleri Dergisi 2021;6(2):236-243. doi: 10.26453/otjhs.849494 


\section{GÍRIŞ}

İnsan vücudunda serbest radikallerin etkisini azaltmak ve oluşturdukları hasarları ortadan kaldırmak için antioksidan sistemler mevcuttur. Oksitadif stres oluşumunu önlemede kritik role sahip olan 'Tiyoller (T)' serumdaki en önemli antioksidanlardır. ${ }^{1}$ Tiyollerin, taşıdıkları sülfidril grupları, oksidan moleküllerce oksitlenerek geri dönüşebilir disülfit (D) bağ yapısını oluşturur. Oluşan disülfit (D) bağ yapıları tekrar T gruplarına redükte edilebilir ve böylece tiyol-disülfit dengesi (TDD) sürdürülür (Sekil 1). ${ }^{2,3}$ Ortamdaki aşırı miktarda serbest oksijen radikalinin nötralizasyonu $\mathrm{T}$ düzeylerini azaltırken, $\mathrm{D}$ düzeyini ise artırır.

TDD organizmada; antioksidan koruma, detoksifikasyon, apoptosis, enzimatik aktivitenin düzenlenmesi ve hücresel sinyal mekanizmalarında etkin rol alır. $\mathrm{Bu}$ bozulmalara bağlı olarak kronik böbrek hastalığı, karaciğer bozuklukları, diyabet, kanser, kardiyovasküler hastalıklar ve preklampsi gibi çeşitli hastalıklar ortaya çıkabilir. ${ }^{3-8}$ Benzer şekilde yaşa bağlı makula dejenerasyonu, santral seröz retinopati gibi çeşitli göz hastalıklarında da bu dengenin bozulduğu gösterilmiştir., ${ }^{9,10}$

TDD, tek taraflı olarak eskiden beri ölçülebilirken, yeni geliştirilen kalorimetrik yöntemle çift taraflı, daha pratik, ucuz ve güvenilir olarak ölçülebilmektedir. $^{11,12}$

Diyabette; gerek uzamış hiperglisemi, gerekse artmış glikozilasyon son ürünlerinin neden olduğu inflamasyon yüzünden antioksidan denge bozulmaktadır. Ayrıca, diyabetik retinopati (DRP) gelişiminde hastalığın süresi ve kötü hiperglisemik kontrol etkilidir. DRP' nin hangi hastada, ne zaman ortaya çıkacağını kestirmek zordur. Diyabetes mellitus ve $\mathrm{T}$ seviyeleri arasındaki ilişkinin araştırıldığ çalışmalar yapılmış olmakla birlikte, diyabetik retinopatide TDD' nin bu yeni ölçüm yöntemiyle değerlendirildiği çalışma sayısı literatürde azdır. ${ }^{13,14}$ Çalışmamızda çift taraflı ölçüm yapılabilen bu yeni yöntemle; diyabeti olup retinopatisi olanlar, retinopatisi olmayanlar ve kontrol grubunda, T ve D düzeylerinin karşılaştırılması amaçlandı.

\section{MATERYAL VE METOT}

$\mathrm{Bu}$ çalışma prospektif, kontrollü bir çalışma olup, çalışma için Erciyes Üniversitesi Klinik araştırmalar etik kurulundan izin alındı (Tarih: 09.01.2015, karar no: 2015/16). Çalışmamız Helsinki Deklerasyonuna uygun yapılmış, tüm katılımcılardan yazılı ve sözlü onam alınmıştır.
Görme keskinliğinin 0,8 ve üzeri olması, Diyabetes mellitus dışında herhangi bir hastalığın olmaması, sferik eşdeğeri $+3 /-3$ aralığında olması, kabul kriterleri olarak; bu şartlara uymamak, glokom veya retinayı etkileyebilecek herhangi bir oküler hastalığı olmak, proliferatif diyabetik retinopatisi olmak veya klinik anlamlı makular ödemli olmak çalışmaya dahil edilmeme kriterleri olarak belirlendi.

Çalışmamıza Kayseri Eğitim ve Araştırma Hastanesi göz kliniğinde rutin takipleri yapılan diyabetli hastalardan belirlenen kriterlere uyan kişiler alındı. Çalışmaya alınan hastalara benzer demografik özelliklere sahip gönüllü kişilerden de kontrol grubu oluşturuldu.

Tüm hastalara rutin göz muayenesi, görme keskinliği, göz içi basıncı ölçümü, ön segment muayenesi, 90 Dioptri lens eşliğinde dilate fundus muayenesi yapıld1. Diyabeti olup retinopatisi olmayanlar bir grubu (DMG, $n=21$ ), diyabeti ve retinopatisi olanlar diğer bir grubu (DRPG, n=22) oluştururken, gönüllülerden oluşan sağlam kişiler kontrol grubunu (KG, $\mathrm{n}=20$ ) oluşturdu. DRP tanısı klinik muayeneye göre konuldu.

Oftalmolojik muayeneyi takiben tüm hastalardan en az 8 saatlik açlık sonrası rutin alınan venöz kan numuneleri santrifüj edildi. Neşelioğlu ve Erel'in bulduğu yöntemle dinamik TDD değerleri ölçüldü. ${ }^{12} \mathrm{Bu}$ yöntemde tiyol disülfit homeostazı, esas olarak nativ tiol (-S-H) (NT) ve indirgenebilir dinamik disülfit (S-S) miktarları ölçülerek belirlenmektedir.

$\mathrm{Bu}$ yeni testte, disülfit bağlarını serbest fonksiyonel tiyol grupları oluşturacak şekilde indirgemek için sodyumborohidrit (NaBH4) kullanılmaktadır. Mevcut tiyol gruplarının ve indirgenmiş tiyol gruplarının toplamı, toplam tiyolü $(\mathrm{S}-\mathrm{S})+(-\mathrm{SH})$ verir. Dinamik disülfit miktarı, toplam tiyol ve doğal tiyol değerleri arasındaki farkın yarısı olarak otomatik olarak hesaplanabilen bir değerdir. Doğal tiyoller (-SH) ve toplam tiyoller belirlendikten sonra disülfit (-SS) miktarları, disülfit/toplam tiyol yüzde oranları (-SS/$\mathrm{SH}+$-SS) (D/TT), disülfit/doğal tiyol yüzde oranları (-SS/-SH) (D/NT) ve doğal tiyol/toplam tiyol yüzde oranları (-SH/-SH + -SS) (NT/TT) hesapland1. Otomatik klinik kimya analizörü (Cobas c501, Roche) kullanılarak ölçümler yapıldı ve sonuçlar $\mu \mathrm{mol} / \mathrm{L}$ olarak sunuldu.

Ístatistiksel Analiz: Tüm istatistiksel analizler Mac OS için olan IBM SPSS 26.0 sürümü (SPSS, Inc, Chicago, IL) kullanılarak yapıldı. Sürekli değişkenler ortalama \pm standart sapma $(\mathrm{M} \pm \mathrm{SD})$ ile ifade edildi. Nitel değişkenleri değerlendirmek için Pearson ki 
-kare testi kullanıldı. Normal dağılım KolmogorovSmirnov testi ile yapıldı. Varyansların homojenliği Levene testi kullanılarak analiz edildi. Parametrik istatistikler için, normal dağılıma sahip veriler tek yönlü varyans analizi kullanılarak gerçekleştirildi. Anlamlı bir sonuç elde edildiğinde, post hoc karşılaştırmalar için Tukey testi kullanıldı. Parametrik olmayan istatistikler için, veriler Kruskal-Wallis testi kullanılarak analiz edildi. Anlamlı bir sonuç elde edildiğinde, post hoc karşılaştırmalar için Bonferroni düzeltmeli Mann-Whitney $U$ testi kullanıldı. P değeri 0,05'ten küçük olarak saptandığında istatistiksel olarak anlamlı kabul edildi.

\section{BULGULAR}

Gruplar arasında yaş, cinsiyet dağılımı, göz içi basınc1, göz ön arka uzunluğu, siferik eşdeğer, açısından anlamlı fark bulunmadı $(\mathrm{p}>0,05)$. Gruplara ait demografik veriler detaylı olarak Tablo 1'de gösterilmektedir.

Glikozile hemoglobin (HbA1C) ve açlık kan şekeri (AKŞ) KG'na göre DMG ve DRPG'ta beklenildiği üzere istatistiksel olarak anlamlı derecede artmıştı $(\mathrm{p}<0,001)$. Ayrica DRPG'ta, DMG' tan anlamlı derecede yüksek bulundu $(\mathrm{p}<0,05)$. Diyabet süresi de DRPG' ta DMG'a göre istatistiksel olarak anlamlı derecede daha fazla idi. Gruplara ait kan şekeri değerleri de Tablo 1'de görülmektedir.

Nativ Tiyol (NT), Total Tiyol (TT) değerleri açısından gruplar arasında anlamlı bir fark bulunmadı $(\mathrm{p}=0,575, \mathrm{p}=0,720)$

D seviyesi, $K G$ ' a göre DMG ve DRPG' unda istatistiksel olarak anlamlı derecede artmış bulundu, fakat DMG ile DRPG arasında anlamlı bir fark bulunmadi $(\mathrm{p}<0,001)$.

D/NT, DMG ve DRPG'ta KG'e göre istatistiksel olarak anlamlı derecede artmıştır $(p<0,05)$, fakat DMG ile DRPG arasinda anlamlı bir fark yoktu $(p=0,865) . D / T T, K G$ 'a göre DMG ve DRPG' ta istatistiksel olarak anlamlı derecede artmışken $(\mathrm{p}<0,05)$; DMG ile DRPG arasında anlamlı bir fark yoktu $(p=0,884)$. NT/TT, KG'a göre DMG ve DRPG'ta istatistiksel olarak anlamlı derecede artmış iken $(p<0,05)$, DMG ile DRPG arasında anlamlı bir fark yoktu $(p=0,865)$. TDD ile ilgili veriler ve değerlendirmeler Tablo 2' de görülmektedir.

\section{TARTIŞMA VE SONUÇ}

Organizmada oksidatif stresin uzaması durumunda; $\mathrm{T}$ seviyesi azalırken, D oranı artmaktadır. Bunun sonucu olarak TDD, D lehine değişmektedir (Șekil 1). Çalışmamızda da D seviyesi, DRP' si olan ve olmayan diyabetli gruplarda kontrol grubuna göre anlamlı olarak yüksek bulunurken, T seviyesi gruplar arasında farksız bulundu. Beklenildiği şekilde diyabetik hastalarda TDD’nde, D lehine değişim bulundu.

Ateş ve ark., Tip 1 DM' lu hastalarda tiyol disülfit seviyeleri ve inflamatuar mediyatörleri değerlendirdikleri çalışmalarında, tiyol seviyesinin azaldığını ve disülfit oranının arttığını göstermişlerdir. ${ }^{15} \mathrm{D}$ 'teki artıştan kronik inflamasyonun ve uzamış hipergliseminin sorumlu olabileceği vurgulanmıştır. Çalışmamızdan farklı olarak bu çalışmada, C reaktif protein (CRP) gibi inflamasyonu gösteren diğer parametrelere de bakılmış ve $\mathrm{T}$ seviyesindeki düşüşten inflamasyonun da sorumlu olabileceği belirtilmiştir. Çalışmamız da sadece T ve D seviyeleri ölçüldü ve $\mathrm{T}$ seviyeleri açısından gruplar arasında anlamlı fark bulunmamıştır. Ancak bu çalışmaya benzer olarak D seviyeleri diyabetli ve DRP'li hastalarda yüksek bulundu. Bu çalışmada vurgulandığı gibi TDD'de D lehine değişimler gözlendi.

Başkol ve ark.'nın retinopatisi olan ve olmayan diyabetliler ile kontrol grubunda; $\mathrm{T}$ seviyesi ve ileri glikozilasyon ürünlerini değerlendirdikleri çalışmalarında, T seviyeleri ve hastalık arasında istatistiksel anlamlı bir ilişki gösterilememiştir. ${ }^{13}$ Fakat ileri glikozilasyon ürünleri ile diyabetik retinopati ve diyabet arasında bağlantı kurmuşlardır. Benzer şekilde biz de T seviyeleri açısından gruplar arasında fark bulamadik.

Retinopatili ve retinopatisiz tip 2 diyabetlilerde ve kontrol gruplarında serum ve aköz sıvılarında T seviyesini çalışan Kırboğa ve ark., serum T seviyelerinde diyabetik ve DRP'lilerde azalma bulurken, aköz T seviyelerinde gruplar arasında fark bulamadıklarını belirtmişlerdir. ${ }^{14}$

Önceden tek taraflı ölçüm yapan kitlerin kullanıldığı çeşitli çalışmalarda da diyabetik hastalarda T seviyesinin kontrol grubuna göre düşük bulunduğu bildirilmiştir. Ancak bu çalışmalarda genel olarak D seviyeleri bakılmamıştır. ${ }^{16,17}$ Farklı bir yaklaşım olarak intraselüler $T$ 'ün en büyük kısmını oluşturan glutatyon seviyesinin ölçüldüğü bir çalışmada glutatyon düzeyinin kontrol grubundan daha düşük olduğu gösterilmiştir. ${ }^{17}$

Çalışmamızla aynı yöntem kullanılarak TDD’ni araştıran yakın zamanlı iki çalışmada da, benzer ve farklı bulgular çıktığı izlenmektedir. Kalaycı ve ark. çalışmasında TT, NT ve D değerleri DRP'li ve makular ödemli grupta diğer gruba göre azalmış olarak bulunurken, D/TT, D/NT oranlarında ise değişim saptanmamıştır. ${ }^{18} \mathrm{Bu}$ çalışmada hastaların 
makular tutulumlu hastalardan seçilmesi özellikle önemlidir, bu hem kötü diyabetik kontrolün hemde hastalığın ileri evresinin bir göstergesi olabilir. Gülpamuk ve ark.'nın çalışmasında ise hastalar göz tutulumu olmayan diyabetli hastalar, göz tutulumu olan ancak proliferatif olmayan diyabetik retinopatili hastalar, göz tutulumu olan proliferatif DRP bulguları olan hastalar şeklinde üç gruba ayrılmış. Çalışmada proliferatif olanlar ile diğer iki grup arasında anlamlı farklar bulunmuştur. ${ }^{19} \mathrm{Bu}$ bulgular bizim çalışmamızdaki bulguları desteklemektedir. Çünkü bizim çalışmamızda da benzer şekilde proliferatif olmayan DRP'li hastalar çalışmaya dahil edilmiştir. $\mathrm{Bu}$ hastalarda da kontrol grubuna göre D miktarları, D/NT ve D/TT artmış olarak bulunmuştur. Fakat göz tutulumu olmayan diyabetlilere göre fark bulunamamıştır. Bu bakımdan göz tutulumu olan ve olmayan diyabetliler arasında fark çıkmamaktadır. T, D miktar ve dengeleri açısından sonuçlarımız bu çalışma ile uyumlu olarak değerlendirilebilir.

Çalışmamızda sağlıklı kontrol grubu ile retinopatili ve retinopatisiz tip 2 diyabetliler karşılaştırıldığında NT ve TT seviyeleri arasında anlamlı fark bulunmad1. Her ne kadar DRP'li grupta diyabetli gruba göre azalma saptandı ise de bu da istatistiksel olarak anlamsız idi. D değerleri kontrol grubuna göre diyabetli ve DRP' lilerde yüksek bulunurken, DRP'si olan ve olmayan diyabetliler arasında anlamlı fark saptanmadi.

Diyabetik retinopati çok geniş bir yelpazede klinik bulgular verdiği için, hastalık aşamasından kaynaklı klinik farklılıklar bu sonuçları doğurmuş olabilir. Ayrıca bireysel farklılıkların da olabileceği göz önünde bulundurulmalıdır.

Sonuç olarak bizim çalışmamızda her iki diyabetli grupta da D seviyesi artmış ve TDD, D lehine değişmiş olarak bulundu. Belki hastalığın ilk aşamalarında $\mathrm{D}$ düzeyindeki bozulma daha belirgin olmakta ve zamanla kısır döngü sürerek T seviyeleri de değişime uğramaktadır. Çeşitli çalışmalardaki farklı sonuçlarda bundan kaynaklanıyor olabilir. Bu durumu daha iyi açıklayabilecek prospektif randomize kontrollü çalışmalara ihtiyaç vardır.

Etik Komite Onayı: Çalışma için Erciyes Üniversitesi Klinik araştırmalar etik kurulundan izin alındı (Tarih: 09.01.2015, karar no: 2015/16 ).

Çıkar Çatışması: Yazarlar çıkar çatışması bildirmemektedir.

Yazar Katkıları: Fikir - IY; Denetleme - NB, IÇ, E.P, SDS; Malzemeler - IÇ, EP, SDS; Veri toplanması ve/veya işlemesi - IÇ, NB, EP, ÖE, AŞ; Analiz ve/veya yorum - IYY, N.B., ÖE, AŞ; Yazıyı yazan IYY, NB.

Hakem değerlendirmesi: Dış bağımsız.

\section{KAYNAKLAR}

1. Sen CK, Packer L. Thiol homeostasis and supplements in physical exercise. Am J Clin Nutr. 2000;72:653-669.

2. Cremers CM, Jakob U. Oxidant sensing by reversible disulfide bond formation. J Biol Chem. 2013;288:26489-26496.

3. Yuvaci HU, Akdemir N, Bostanci MS, et al. Evaluation of the level of thiol-disulphide homeostasis in patients with mild and severe preeclampsia. Pregnancy Hypertens. 2016;6(4):394399.

4. Biswas S, Chida AS, Rahman I. Redox modifications of protein-thiols: emerging roles in cell signaling. Biochem Pharmacol. 2006;71(5):551564.

5. Circu ML. Aw TY. Reactive oxygen species, cellular redox systems, and apoptosis. Free Radic Biol Med. 2010;48(6):749-762.

6. Matteucci E, Giampietro O. Thiol signalling network with an eye to diabetes. Molecules. 2010;15(12):8890-8903.

7. Prabhu A, Sarcar B, Kahali S, et al. Cysteine catabolism: a novel metabolic pathway contributing to glioblastoma growth. Cancer Res. 2014;4 (3):787-796.

8. Rodrigues SD, Batista GB, Ingberman M, Pecoits-Filho R, Nakao LS. Plasma cysteine/cystine reduction potential correlates with plasma creatinine levels in chronic kidney disease. Blood Purif. 2012;34(3-4):231-237.

9. Elbay A, Ozer OF, Akkan JCU, et al. Comparison of serum thiol-disulphide homeostasis and total antioxidant-oxidant levels between exudative age-related macular degeneration patients and healthy subjects. Int Ophthalmol. 2017;37 (5):1095-1101.

10. Turkoglu EB, Dikci S, Çelik E, et al. Thiol/ disulfide homeostasis in patients with central serous chorioretinopathy. Curr Eye Res. 2016;41 (11):1489-1491.

11. Ellman G, Lysko H. A precisemethodforthedetermination of plasmasulfhydrylgroups. Anal Biochem.1979;93(1):98-102.

12. Erel O, Neselioglu S. A novel and automated assay for thiol/disulphide homeostasis. Clin Biochem. 2014;47:326-332. 
13. Baskol G, Gumus K, Oner A, Arda H, Karakucuk $\mathrm{S}$. The role of advanced oxidation of protein products and total thiols in diabetic retinopathy. Eur J Ophthalmol. 2008;18:792-800.

14. Kirboga K, Ozgec AV, Kosker M, et al. Retinopathy and levels of ischemia-modified albumin, total thiol, total antioxidant capacity, and total oxidative stress in serum and aqueous humor. J Ophthalmol. 2014;2014:820-853. doi:10.1155/2014/820853

15. Ates I, Kaplan M, Yuksel M, et al. Determination of thiol/disulphide homeostasis in type 1 diabetes mellitus and the factors associated with thiol oxidation. Endocrine. 2016;51(1):47-51.

16. Ceriello A, Bortolotti N, Falleti E, et al. Total radical-trapping antioxidant parameter in NIDDM patients. Diabetes Care. 1997;20(2):194 $-197$.

17. Yazıcı AE, Paşaoğlu H, Doğan Y, et al. Tip 2 diyabetes mellituslu hastalarda plazma total tiyol ve eritrosit redükte glutatyon düzeyleri. Turkiye Klinikleri Journal of Medical Sciences. 2002;22:487-492.

18. Kalayci M, Cetinkaya E, Yigit K, et al. IschemiaModified albumin levels and thiol-disulphide homeostasis in diabetic macular edema in patients with diabetes mellitus type 2. Curr Eye Res. 2020;14:1-6.

19. Gülpamuk B, Tekin K, Sönmez K, et al. The significance of thiol/disulfide homeostasis and ischemia-modified albumin levels to assess the oxidative stress in patients with different stages of diabetes mellitus. Scand J Clin Lab Invest. 2018;78(1-2):136-142. 
Tablo 1. Çalışmaya dahil edilen hastalara ait demografik veriler.

\begin{tabular}{|l|c|c|c|}
\hline & KG (n=20) & DMG (n=21) & DRPG (n=22) \\
\hline Y & $54,20 \pm 14,89$ & $56,59 \pm 12,23$ & $58,80 \pm 8,51$ \\
\hline C(K/E) & $10 / 10$ & $11 / 11$ & $10 / 11$ \\
\hline Se & $0,53 \pm 1,08$ & $0,10 \pm 1,44$ & $0,15 \pm 0,86$ \\
\hline GíB & $15,60 \pm 2,90$ & $17,31 \pm 1,98$ & $16,57 \pm 2,08$ \\
\hline AL & $22,93 \pm 0,69$ & $23,16 \pm 0,75$ & $23,43 \pm 0,71$ \\
\hline AKS & $97,35 \pm 9,52$ & $177,59 \pm 63,99$ & $245,80 \pm 89,32$ \\
\hline HbA1 C & $5,44 \pm 0,31$ & $8,92 \pm 2,76$ & $10,17 \pm 2,17$ \\
\hline DS & 0 & $7,18 \pm 3,4$ & $11,09 \pm 5,40$ \\
\hline
\end{tabular}

KG: Kontrol Grubu; DMG: Diyabetes Mellitus Grubu; DRP: Diyabetik Retinopati Grubu; Y: Yaș; C: Cinsiyet; K: Kadın; E: Erkek; Se: Siferik Eşdeğer; GiB: Göz içi basıncı; AL: Ön arka göz uzunluğu; AKȘ: Açlık Kan Şekeri; DS: Diyabet Süresi. Veriler ortalama ve standart sapma olarak belirtildi $(\mathrm{M} \pm \mathrm{SD})$. 
Tablo 2. Gruplara göre tiyol disülfit değer ve oranlar1.

\begin{tabular}{|l|l|l|l|l|l|l|}
\hline & TT & NT & D & D/NT & D/TT & NT/TT \\
\hline $\begin{array}{l}\text { KG } \\
(\mathbf{n = 2 0})\end{array}$ & $375,18 \pm 64,92$ & $345,98 \pm 62,035$ & $14,60 \pm 3,68$ & $4,30 \pm 1,17$ & $3,94 \pm 0,97$ & $92,10 \pm, 95$ \\
\hline $\begin{array}{l}\text { DMG } \\
(\mathbf{n = 2 1})\end{array}$ & $402,97 \pm 100,55$ & $361,389 \pm 9,11$ & $20,79 \pm 3,32$ & $5,99 \pm 1,28$ & $5,32 \pm 1,02$ & $89,34 \pm 2,06$ \\
\hline $\begin{array}{l}\text { DRPG } \\
(\mathbf{n = 2 2})\end{array}$ & $370,29 \pm 64,40$ & $329,09 \pm 63,28$ & $20,60 \pm 2,52$ & $6,46 \pm 1,28$ & $5,70 \pm 1,01$ & $88,59 \pm 2,03$ \\
\hline $\boldsymbol{p}$ & ${ }^{\mathrm{a}} 0,720$ & ${ }^{\mathrm{a}} 0,575$ & ${ }^{\mathrm{a}}<0,0001$ & ${ }^{\mathrm{b}}<0,05$ & ${ }^{\mathrm{b}}<0,05$ & ${ }^{\mathrm{b}}<0,05$ \\
\hline
\end{tabular}

TT: Total Tiyol; NT: Doğal Tiyol; D: Disülfit; KG: Kontrol Grubu; DMG: Diyabetes Mellitus Grubu; DRP: Diyabetik Retinopati Grubu; Veriler ortalama ve standart sapma olarak belirtildi $(\mathrm{M} \pm \mathrm{SD})$; a: Kruskal Walis; b: One Way Anova. 


\section{$R=S H+R=S H+O=R-S-S-R+H, O$}

Şekil 1. Tiyol disülfit dengesinin şematik gösterimi. ${ }^{3}$ 